THE NATURAL HISTORY OF THE FARM. 


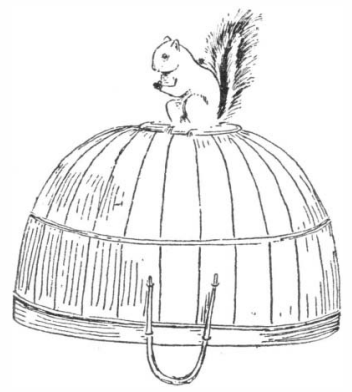




\section{The Natural History of the Farm}

A Guide to the Practical Study of the Sources of Our Living in Wild Nature.

\section{By JAMES G. NEEDHAM}

PROFESSOR OF LIMNOLOGY, GENERAL BIOLOGY AND NATURE STUDY IN CORNELL UNIVERSITY. 


\section{CYBELE}

Spirit of th' raw and gravid earth

Whenceforth all things have breed and birth,

From palaces and cities great

From pomp and pageantry and state

Back I come with empty hands

Back unto your naked lands.

一L. H. Bailey.

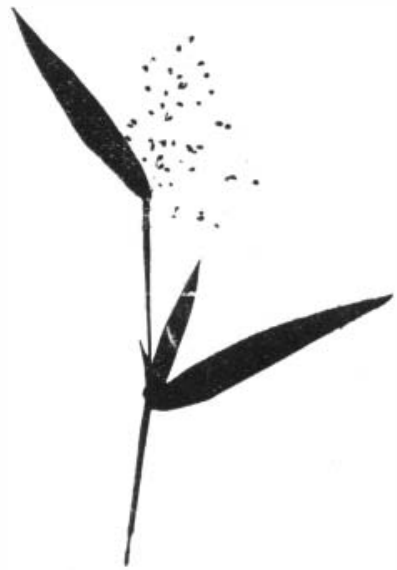

COPYRIGHT, I9I 4

BY THE

COMSTOCK PUBLISHING COMPANY

PRESS OF W. F. HUMPHREY. GENEVA, N. Y. 
Open access edition funded by the National Endowment for the Humanities/Andrew W. Mellon Foundation Humanities Open Book Program.

Copyright (C) 1916 by Comstock Publishing Company

First paperback printing 2019

The text of this book is licensed under a Creative Commons Attribution-NonCommercial-NoDerivatives 4.0 International License: https://creativecommons.org/licenses/by-nc-nd/4.0/.

To use this book, or parts of this book, in any way not covered by the license, please contact Cornell University Press, Sage House, 512 East State Street, Ithaca, New York 14850. Visit our website at cornellpress.cornell.edu.

Printed in the United States of America

ISBN 978-1-5017-4076-3 (pbk.: alk. paper)

ISBN 978-1-5017-4077-0 (pdf)

ISBN 978-1-5017-4078-7 (epub/mobi)

Librarians: A CIP catalog record for this book is available from the Library of Congress 